\title{
That certain feeling: blues and jazz .... in 1890?
}

\author{
PAUL OLIVER
}

'And this, after all, we do know with certainty: that in the 1880s in and around New Orleans and in other parts of the South, they were beginning to play the music we call jazz.' So wrote Barry Ulanov who was convinced that jazz 'reached back to the twelve bar form of the folk tune . . . and evolved that most durable and most thoroughly adaptable of jazz forms, the blues'. Picked out by 'men and women in the backwoods and the front parlors making the delicate little changes, insisting upon the famous "blue notes", it took shape 'long before the famous early names of jazz - before Buddy Bolden and Freddie Keppard and Papa Laine" (Ulanov 1958A, p. 17). Ulanov was writing in 1957, more than thirty years closer to the origins of jazz, when a number of the veteran musicians of the first and second generations were still living. His 'certainty' implied that the blues was the wellspring of jazz from which it drew its inspiration and its improvisation.

This was neither the first, nor the last attempt to account for the presence of blues form, inflection and expression in jazz; there have been many others and with every history of jazz there will inevitably be more. For there seems to have been little doubt about historians of jazz that blues played an essential part in its formation. 'The blues, a vocal music, lies at the root of jazz and, though it may seem a fanciful statement, the whole of jazz is a kind of extension of the blues', explained John Postgate in 1973, in his 'plain man's guide' to jazz (Postgate 1973, p. 124). Dan Morgenstern in Jazz People made an even more extravagant claim, asserting that 'the blues is the strain that runs through all American popular music and makes it unique (Morgenstern 1976, p. 26). But that was in 1976; no writers gave blues a prominent position in the history of popular music until after the rock revolution of the late 1950s. The part played by blues in jazz continued to be emphasised in jazz histories. In their introduction to the subject published in 1984 Donald D. Megill and Richard S. Demory asserted that the blues is the root and foundation upon which all jazz has developed. Indeed, without the blues there would be no jazz as we know it today'. When it came to accounting for the origins of the blues they were more equivocal. Hinting that the spirituals arose in the period 1780-1871 they stated without examples, and without specifically naming blues, that 'in addition to the spirituals, secular songs dealing with loneliness, infidelity, rootlessness or repression also began to appear ... passed on orally' (Megill and Demony 1984, p. 4).

With all this agreement on the blues as a precursor of, and influence on jazz it seems strange that hardly any writers cared to comment on the fact that, in John Chilton's words, 'the one form of music not mentioned in any of the early contemporary accounts of festivities in New Orleans was the blues'. Unfortunately he 
did not permit his curiosity to take him any further along that road; instead he added his definition that the blues were the indigenous American music that came into being when the black slaves sang their variations of European folk-songs' hence, before 1860 (Chilton 1978, p. 15).

In my entry 'Blues' in The New Grove Dictionary of Jazz (Oliver 1988, pp. 121-8), I brought into question some of the conventional ideas of how the process came about, but had insufficient space in which to enlarge upon it further. The debate about the blues element in jazz is partly about the musical characteristics, partly about matters of history. Many writers have attempted to examine one or the other and sometimes both, for those aspects of jazz tonality, form and expression which are acknowledged as being essentially of the blues inevitably raise the issue of their source and the nature of their influence. The historical problems of blues influence on jazz revolve around a number of questions: did blues precede jazz, and if so, when and where did it originate? Were there blues singers and musicians in New Orleans and if so, from what date? Was blues known to the early jazz musicians and to what extent did they listen to blues and adopt it in their playing? The answers to these problems must relate to the whole question of the origins of the blues. Then there are the problems of identifying and accounting for its first appearance in New Orleans. Some of the answers might possibly be found in documentary or other evidence of the blues in early jazz, in the recollections of veteran musicians and their hearers of blues playing by early jazzmen, in the recordings of New Orleans musicians made in the 1920 s or the reconstructions from the 'revival' period. It is the job of the historian who writes a comprehensive history of any subject to bring to bear all the evidence that he (or she, but there have been none for the early history of jazz, as yet) can adduce. In the process he may draw upon former writings, specialised articles, interviews, documentary research and the like, coordinated in an overview of the phenomenon, supported as may be necessary by theory.

For now I shall confine myself to the question 'how did jazz historians account for, and approximately date, the origins of the blues, and what part did they demonstrate that the blues played in the formative years of jazz?'. What I am concerned with here, is what the jazz historians concluded from all the evidence they considered, an enquiry which I consider to be a necessary preliminary to any further investigation.

'When the orchestra settled down to the slow blues, the music was mean and dirty.' The orchestra was Buddy Bolden's: 'and with the final exhortation "Oh you bitches, shake your asses" he cracked down on the blues'. The image evoked by Frederic Ramsey Jr and Charles Edward Smith in Jazzmen was a vivid one, and for many years jazz writers drew upon their descriptions, not only of Bolden's band playing the blues, but of the dances in Congo Square which were not discontinued, they stated, until Bolden was in his teens. As Henry Kmen has shown conclusively, the evidence concerning Congo Square was erroneous, but it was often quoted (Kmen 1972, pp. 5-16). In an essay 'Blues' in Jazzmen, E. Sims Campbell was also the source of many statements concerning the blues, 'the gateway to freedom for all American Negroes'. But he had a novel theory about ragtime 'which was patterned after the blues. The blues were so essential a part of Negro life that many musical pioneers rightly felt that America would not accept them, thus this offshoot, ragtime' (Ramsey and Smith 1939, pp. 13, 105, 114).

Campbell criticised the intellectual approach to blues that borders on the 
ridiculous' of the French jazz critic Hugues Panassié. Nearly fifty years ago Hugues Panassié contended that the intonation and expression employed by jazz musicians 'grew out of the style of interpretation of the negro singers. These singers, in translating their lamentations, use frequent glissandoes of a quarter tone, or a half tone, or of even a broader interval', and he observed that jazz musicians 'even when playing music other than blues, employ the style of interpretation to which blues gave birth' (Panassié 1942, pp. 45, 47). A number of later authors did not significantly differ in this view, though some enlarged upon the supporting evidence. Panassié did not attempt to trace the origins of blues, or even of blues in New Orleans, but in another work he claimed that it is 'certain that they were sung in the United States before Emancipation ... After the abolition of slavery the blues were still sung' (Panassié 1956, p. 33).

It is best to draw a discreet veil over Rudi Blesh's essay 'Jazz Begins' in Jazzways in which he described a 'beater' in a dark corner, 'hunched over the battered upright piano ... a lonely figure, tapping his foot, humming in a rough voice the bare and melancholy phrases, the dark words "Got to keep movin', blues fallin' down like hail"' '. (For any reader unaware of the fact, the blues quoted was recorded by the Mississippi guitarist Robert Johnson, in 1937 - and only by him over forty years or more after the implied date of the fantasised account.) 'About 1885 jazz began to develop into its next period, the classic', the author continued (Blesh 1946, p. 15).

Aware perhaps, of the shortcomings of the earlier piece of romanticised writing on blues which he contributed to Jazzways, Rudi Blesh wrote a full-length book, Shining Trumpets, a work which gave more informed attention to blues than any other jazz history. He summarised the nature of blues polytonality, of blue notes, of the blues scale derived from the conjunction of 'African scales' and the diatonic western scales. And there were features of his own naming, such as off-pitchness, language quality, 'the tone clusters that are known as blue', and the cyclic nature of blues stanzas: 'in these ceaseless cycles unfolding like a spiral, the music seems like a phenomenon of nature itself'. When did all this come about? 'The blues had undoubtedly appeared in their established form by 1870, although even an approximate date must remain conjectural. It is certain, however, that the blues were established, in some of their variant forms, quite early, and more or less simultaneously throughout the South' (Blesh 1949, pp. 104-8). The first phase of the blues he dubbed archaic, or pre-classic; the next phase occurred when the blues appeared in the cities, including of course, New Orleans. But in a subsequent chapter, 'Beginnings of Jazz', Blesh made no mention of blues; to him it was a distinct genre.

Romantic though some of Blesh's writing was, presumably to make up for the lack of any hard data, at least it did not stem from the kind of contempt openly expressed by André Hodeir who, referring to the possible 'freer form' of early blues, wrote that 'a vestige of such liberty appears in the lack of concern a minstrel like Big Bill Broonzy has for such construction and even for the unity of the measure' (Hodeir 1956, p. 234). Hodeir concluded that 'it definitely seems that most of the repertory of the first Negro bands . . consisted not of blues, but of military marches, quadrilles and polkas' (citing 'such pioneers as the Original Zenith Brass Band' - recorded 1946 - as an example). The most authentic of blues singers he suggested, when 'compared with the singers of the dark Continent' were 'Europeanised'. The Zenith session was arranged in fact, by Rudi Blesh, 
whose arguments for the African elements in jazz were the target of much of Hodeir's criticism. Jazz could not be seen 'as anything but the denial of a centuriesold, static African conception, with its leaning toward incantation, in favour of another conception, European in origin, and based on the development of thought'. How an African concept was arrived at without thought he did not venture to say. Somewhat surprisingly he credited the 'clash of blues and military marches' that transformed 'an almost motionless folklore into an art capable of all kinds of evolution'. But he did not indicate when (ibid. pp. 43-4).

Books are by their nature sequential and any author of an historical work has the problem of combining the integral and evolutionary nature of a specific subject within his main theme, with its historical place within the narrative as a whole. Jazz historians have to cope with this problem as do any others, and the placing of blues within the unfolding sequence of their books presents this very problem. Robert Goffin, in Jazz From the Congo to the Metropolitan (1948) buried blues in the sixteenth chapter out of eighteen, 'From Spirituals to Boogie Woogie'. In Jazz in Perspective, which was subtitled 'The Background to the Blues', Iain Laing discussed blues briefly near the commencement of his book but devoted two chapters to it at the end. 'Jazz is a city music', he emphasised, and later referred to blues too, as 'a product of the cities', stating notoriously that 'the blues is not the whole of jazz, but the whole of the blues is jazz, having no existence apart from this idiom' (Laing 1946, pp. 3, 102-3).

That same year saw the appearance of $A$ Critic Looks at Jazz published by Jazz Music Books, previously published in serial form in The Record Changer. Its author, Ernest Borneman, a former student of Erich von Hornbostel, was probably the most diversely talented historian jazz ever had, able to draw on a wide range of references to support his arguments. But he took a surprisingly determinist line when, after discussing African musical traits he concluded that 'all these elements drove American Negro music quite inexorably towards one form . . This form was the blues' which he stated, developed 'during the Civil War years'. Borneman concluded in an untypically purple passage, that 'there is little doubt that the only jazz that has not dated, and is not likely to date, is this blues . . . the blues is truly the heart of jazz and jazz, without the blues, will expire as surely as a man's body when his heart ceases work' (Borneman, 1946, pp. 10, 40).

Borneman's belief in the blues as essential to jazz was restated somewhat more moderately by Rex Harris in his 1952 Pelican paperback, simply entitled Jazz. The book's total disregard of modern jazz excited a great deal of adverse, and merited, criticism at the time. Harris was an unrepentant 'mouldie fygge' in the jazz slang of the period, but he included a great deal of information not to be found elsewhere - such as extracts from the texts of the 'Black Codes'. He discussed slave work songs and was 'certain however, that tribal Work Songs which started life in West Africa ... were one of the stepping stones to the Blues - one of the mainstays of jazz'. Undoubtedly, in Harris's view, the Blues arose following Emancipation. He intentionally omitted any discussion of Ma Rainey and Bessie Smith because he said, they were 'influenced by jazz. But they did not influence the course of jazz' (Harris 1952, pp. 31, 9).

Probably the best-selling jazz history of the 1950s was A Pictorial History of Jazz by Orrin Keepnews and Bill Grauer. Its visual nature meant that the text was minimal. On the first page they referred to the bare dance-halls where Bolden pounded out his low-down blues' but it was not until Chapter 6 that they con- 
sidered the subject. "The blues dates back before the beginnings of jazz, and its origins are obscure beyond any hope of precise documentation, although it must have come into being somewhere in the deep rural South, sometime before the turn of this century'. Their few comments were hedged by 'probably' and 'possibly' but 'certainly some incredibly rich and moving singing and accompaniment and some highly effective folk-poetry belongs to this tradition, and instrumental blues have greatly enriched the mainstream of jazz'. Keepnews and Grauer were hardly reliable authorities: concluding their section on blues with a photograph of Leadbelly they asserted that 'when he died, in 1949, it could readily be said that the story of the traditional blues as a living, creative force had come to its end' (Keepnews and Grauer 1955, pp. 3, 69, 79).

Another work which originally dated from 1953, though it had to wait over twenty years for Dan Morgenstern's translation into English, was Joachim Berendt's The Jazz Book. Berendt eventually came to the blues in a discussion of the elements of jazz, but though he referred to the 'old, primitive blues' (citing Big Bill Broonzy), and 'the great "classical" period', he gave no dates. The only clue to his view on the origin of the relationship of blues to jazz was a chart of "The development of jazz (with the blues as backbone)' which indicated that blues preceded jazz and fed into it (Berendt 1975, pp. 139, 5).

This clouding of the issue by hinting at the origins of blues and its influence and then burying it deep in the text of a history was employed by a number of writers: Marshall Stearns, for instance. It took Stearns in his standard work, The Story of Jazz, a hundred pages before he reached the blues, having already dealt with 'The Pre-History of Jazz' and 'New Orleans'. 'The blues are at the centre of the jazz tradition and date back to the earliest days of jazz', he observed (Stearns 1957, p. 99). Noting that the date of the first blues would probably never be known, he stated incautiously that 'the more we learn, the earlier it seems to have been'. He quoted Russell Ames's contention that 'African songs of proverbial wit and ridicule were one likely source, and African songs of pity and sorrow another' and what he had to say about the blues was summarised in fewer than eight pages.

A couple of years later, Barry Ulanov's A History of Jazz in America took up the theme. 'Many of the songs of the [eighteen] seventies and eighties celebrated the good times in town. On the plantation, lyric characterisation was given the plantation enemy, the boll weevil', he wrote, quoting Leadbelly's version of the ballad. 'Later there were songs about the prodigious exploits of heroes which became the legend of John Henry . . . All these in later evolutions became the material of blues lyrics.' Ulanov's history was shaky: the boll weevil was not seen in Texas until the 1890 s while the legend (and ballad) of John Henry preceded it. 'When the spiritual was transformed into the blues, the content shifted some', he asserted without qualification, though 'the twelve-bar form we know as the blues came into its vigorous own in the early years of this century' (Ulanov 1958B, pp. 19, 26).

Under his pseudonym of Francis Newton the Marxist historian Eric Hobsbawm wrote a wide-ranging and perceptive study of the complex milieux of the music in The Jazz Scene. He too, posited a 'pre-history' and a period when 'the sung blues, the heart of jazz, may have emerged in the most primitive forms even before the Civil War, though almost certainly not yet in the standard twelve-bar form, and quite certainly as yet without European or any other harmony'. Blues became instrumental in the bar-rooms and brothels 'most probably in those navvies' and other labourers' camps, perhaps in the South-West. It has been traced 
back to the 1880s.' He did not state by whom (nor where 'navvies' can be found in the United States), but a few pages on he moved to safer ground with the observation that "the "country blues" seems to have emerged as a recognisable form towards the end of the nineteenth century' (Newton 1959, pp. 44, 99). It was evident that the blues was among many forms of music that influenced jazz, military marches and ragtime being recognised by virtually every writer. Few were as liberal with their catalogue of influences as Leroy Ostransky whose The Anatomy of Jazz listed even such unlikely sources of New Orleans jazz as 'candy stews, corn shuckings' and Italian arias; 'above all they knew the blues' (Ostransky 1960, p. 158).

In all the jazz histories that appeared in this prolific period only Leonard Feather's The Book of Jazz seriously questioned the assumptions of origin that lay behind the theories they advanced. Feather conducted a number of interviews with musicians from other regions and this, and his innate scepticism, led him to conclude that 'the esthetic credit properly belongs, as is the case with jazz as a whole, to performers in every populated area in the United States; yet . . . the belief has been sedulously cultivated that the blues was born in New Orleans - another manifestation of a tendency to localize and specialize that has long been an obstacle to a true understanding of the origins of jazz.' He was among the first to acknowledge the European elements in blues, and attempted to present the conflicting views on such aspects as African influence or the controversy as to whether the blues was rural or urban in origin, with fairness. Feather cited a black choir leader, Leonard de Paur who stressed the urban nature of blues: 'Out of this came the blues and out of that the development of jazz. All of these things had a high degree of white origin. People don't like to admit this, because they like to think in terms of complete purity', de Paur said (Feather 1957, pp. 147, 15). But though Feather's book, which promoted a hostile reception at the time, seems more interesting now, he did not succeed in advancing any theory as to how, or when, the processes took place.

After the spate of histories of jazz in the 1950s there were fewer books that seriously reflected on the problems of the influence of blues on the music. One was the first history of jazz written by a black author, Blues People by Leroi Jones (later known as Amiri Baraka). 'The leisure and movement allowed to Negroes after the Civil War helped to standardize the new blues form as well as spread the best verses', he wrote, though he noted that 'the guitar was not commonly played by Negroes until much after the Civil War'. He too, was of the opinion that blues both preceded and shaped jazz, considering it important to note that 'jazz as it developed was predominately a blues-based music' (Jones 1963, pp. 64, 69, 78).

The same year, 1963, Harold Courlander placed 'Blues' in the sequence of his chapters in Negro Folk Music USA before 'Ring Games', 'Louisiana Creole Songs', 'Ballads and Minstrelsy' and 'Dances'. He stopped short of discussing their bearing on jazz, whose enthusiasts are 'prone to think of their art form as a kind of high point in evolution'. In so doing they assigned specific dates and places for the influence of various elements, and he argued that the assumption that blues followed religious songs, work songs etc. was questionable. The persistence of what he called 'archaic blues songs' (using Blesh's term) 'in cultural backwashes of the South along with other Negro songs, both sacred and secular, that clearly antedate the Civil War, suggests that the blues form may be far older than is generally supposed'. Those who date blues by their appearance on record 'might consider 
that about a century intervened between the composition of "The Yellow Rose of Texas" and its performance on recordings' (Courlander 1963, pp. 128, 140). Harold Courlander had conducted extensive field work in Alabama and had recorded many veteran blacks, even some who had been born in slavery.

Early Jazz by the composer and jazz musicologist Gunther Schuller, first published in 1968, was welcomed for its musicological approach - and for the academic respectability of its author. Schuller's conclusions as to the origin of the blues in jazz are as elusive as any when they are subjected to any scrutiny. How and when did the Negro adopt the formal and harmonic foundation of the blues, he asked, 'a foundation the Negro slave certainly did not bring with him from Africa' - certainty was still a characteristic of most of these speculations on origins. For an answer we have to turn to the seventeenth and eighteenth centuries: 'through the years and decades this marvellously rich accumulation began to crystallize into more specific modes of expression: the field holler, the spiritual, the country blues, the work song, the ring shout - all of them strongly related and overlapping'.

As defined by Schuller the blues is 'a form of folk music developed by the Negro slaves in the United States during the nineteenth century', i.e. before 1860 (Schuller 1968, pp. 35, 374). In the 'next decades' following the end of Reconstruction (i.e. after 1870) 'a crude form of blues developed', he stated, though without any supporting evidence, that was 'still more in the realm of sung speech rather than song per se' which had 'migrated to the cities' by the turn of the century. (Possibly, this conclusion was derived from Sidney Finkelstein's Jazz: A People's Music (1948) which asserted that 'the blues were a music of the semi-feudalism that arose in the South after the sabotage of "Reconstruction" ' (p. 91). Nevertheless the blues 'were improvised and as such were more successful in preserving the original and melodic patterns of African music'. Of these the most important was 'the call-andresponse pattern' which he illustrated with the anachronistic choice of Leroy Carr's 'How Long, How Long Blues' (Schuller 1968, pp. 38, 29).

Nearly a decade later, in 1977, Frank Tirro's Jazz: A History was published; it annoyed a number of critics because of the emphasis it gave to early forms of jazz. 'Blues, a parent of jazz, developed during the latter part of the nineteenth century', he stated, but later he thought it possible that 'elements of the blues go back much further, and we will try to trace them back to Africa in the next chapter' a promise that was not fulfilled. A chapter or so on, and he was stating that 'the performance of this distinctive musical type must certainly date back to the beginning of the century' (i.e. 1900s) before deciding that 'country blues has no history to speak of, at least it has no significant chronology'. Not that it mattered for 'blues, except for country blues, have been totally integrated into the jazz repertoire both instrumentally and vocally' (Tirro 1977, pp. 4, 26, 53, 124, 145).

In a much acclaimed book The Making of Jazz: A Comprehensive History ('by far the best . . . the standard work' - Humphrey Lyttleton), James Lincoln Collier did not add to the sum of knowledge on the subject. His observations had a familiar ring: 'the blues as a separate form of music probably began to develop from other black folk forms, especially the work song, in the 1880 s or 1890 s, and was complete as a form by about 1910 '. He was confident that 'by at least 1900 the blues band playing instrumental blues was a standard feature of honky tonks and dance halls', justifying his claim with a vague reference to 'a substantial number of contemporary reports' without, however, citing even one. Yet, 'the streams were converging' 
and 'the years from, let us say, 1895 to 1910 ' saw 'a cadre of New Orleans musicians who were at home in a variety of musics - the blues, rags, marches, popular songs, in many cases themes from overtures and operas, and speciality numbers' (Collier 1978, p. 63).

When, in 1988, James Lincoln Collier wrote his 30,000-word piece on 'Jazz' for The New Grove Dictionary of Jazz he had devoted just half-a-dozen lines to the blues, in which the editorial hand could be detected. "The blues are known to have existed in New Orleans and Mississippi just after 1900', he stated, subsequently clouding the issue of the relationship of blues and jazz by stating of Buddy Bolden, 'the man generally credited with being the first jazz musician', that it was 'almost certain, however, that he played not jazz but ragtime and the blues' (Collier 1988, p. 583). The thin evidence of this was questioned by Max Harrison in an extended essay on jazz in a book jointly written with myself and (on ragtime) William Bolcom. Our decision to keep to our respective patches meant that the common ground between them was not explored; if it did not add to the confusion concerning the bearing of blues upon early jazz, I regret to say that it added nothing to clarify it either (Oliver et al. 1986, p. 235).

It would be possible to continue for several more pages with extracts from jazz histories that state, each with disarming certainty, quite conflicting accounts of the period when blues developed and how it influenced jazz. It is not possible to find a consensus among the jazz historians on these matters: blues began, variously, before the Civil War, during the War, after Emancipation, during Reconstruction, after Reconstruction, in the 1880s, the 1890s. Blues was African in origin, it was not African in character, it was a rural music, it was a city music, it was part of the pre-history of jazz, it was an influence on the formation of jazz, it was part of a convergence phenomenon in the shaping of jazz, it was assimilated by jazz after its marching phase, it was played with ragtime before jazz bands played jazz, it was adopted by ragtime musicians at a later stage, it was, and is, the essence of jazz expression. ...

The role of ragtime, because the published compositions are specifically datable, is less contentious, while the presence in New Orleans of known black brass marching bands in the 1880 s and 1890 s is well-documented. But what is the evidence of the presence of blues in New Orleans as an idiom distinct from jazz which could have exercised an influence upon it? Did New Orleans have a vocal blues tradition? If so, who were its exponents? If not, were its musicians first exposed to blues within the city (and if so, how?) or were they in contact with it while on tour, or in some other way? Were the New Orleans musicians the first to play blues-inflected jazz, or was it developed in another context altogether? The questions still remain. If there was any solid information on this subject it seems to have eluded most jazz historians, though the recollections of various jazz musicians have been cited by some and must be similarly re-examined.

For the present though, to coin a phrase, one thing seems certain. The certainty with which each jazz historian has expressed his opinion served to give a shaky argument the impression of a firm foundation, and successively inhibited the serious research that should, and, in the 1950s if not later, probably could have been done. 


\section{References}

Berendt, Joachim. 1975. The Jazz Book: From New Orleans to Rock and Free Jazz (Frankfurt am Main; New York)

Blesh, Rudi. 1946. In Jazzways, ed. G.S. Rosenthal and F. Zachary (New York) 1949. Shining Trumpets: A History of Jazz (London)

Borneman, Ernest. 1946. A Critic Looks at Jazz (London)

Chilton, John. 1979. Jazz (London)

Collier, James Lincoln. 1978. The Making of Jazz: A Comprehensive History (London) 1988. 'Jazz' in The New Grove Dictionary of Jazz, ed. Barry Kernfeld (London)

Courlander, Harold. 1963. Negro Folk Music, USA (New York)

Feather, Leonard. 1957. The Book of Jazz: A Guide to the Entire Field (London)

Finkelstein, Sidney. 1948. Jazz: A People's Music (New York)

Goffin, Robert. 1943/1946. Jazz: From the Congo to the Metropolitan (Paris, New York)

Harris, Rex. 1952. Jazz (Harmondsworth)

Harrison, Max. 1986. 'Jazz' in The New Grove Gospel, Blues and Jazz, ed. P. Oliver, M. Harrison and W. Bolcom (London)

Hodeir, Andre. 1956. Jazz: Its Evolution and Essence (New York)

Jones, Leroy. 1963. Blues People: Negro Music in White America (New York)

Keepnews, Orrin, and Bill Grauer Jr. 1955. A Pictorial History of Jazz (New York)

Kmen, Henry A. 1972. 'The roots of jazz and the dance in Place Congo: A re-appraisal', Yearbook for International Musical Research, 8.

Laing, lain. 1946. Jazz in Perspective: The Meaning of the Blues (London)

Megill, Donald D. and Richard S. Demory. 1984. Introduction to Jazz History (Englewood Cliffs, NJ)

Morgenstern, Dan. 1976. Jazz People (New York)

Newton, Francis 1959. The Jazz Scene (London)

Oliver, Paul. 1988. 'Blues', in The New Grove Dictionary of Jazz, ed. Barry Kernfeld. (London)

Oliver, Paul, Max Harrison and William Bolcom. 1986. The New Grove Gospel, Blues and Jazz (London)

Ostransky, Leroy. 1960. The Anatomy of Jazz (Seattle)

Panassié, Hugues. 1942. The Real Jazz (New York)

1954/56. Dictionary of Jazz (Paris, London)

Postgate, John. 1973. A Plain Man's Guide to Jazz (London)

Ramsey Jr, Frederic and Smith, Charles Edward (eds.) (1939) 1957. Jazzmen (London)

Schuller, Gunther. 1968. Early Jazz: Its Roots and Musical Development (New York)

Stearns, Marshall. 1957. The Story of Jazz (London)

Tirro, Frank. 1977. Jazz: A History (New York)

Ulanov, Barry. 1958A. A Handbook of Jazz (New York)

1958B. A History of Jazz in America (New York) 